\title{
In Memoriam: Professor Moritaka Hayashi
}

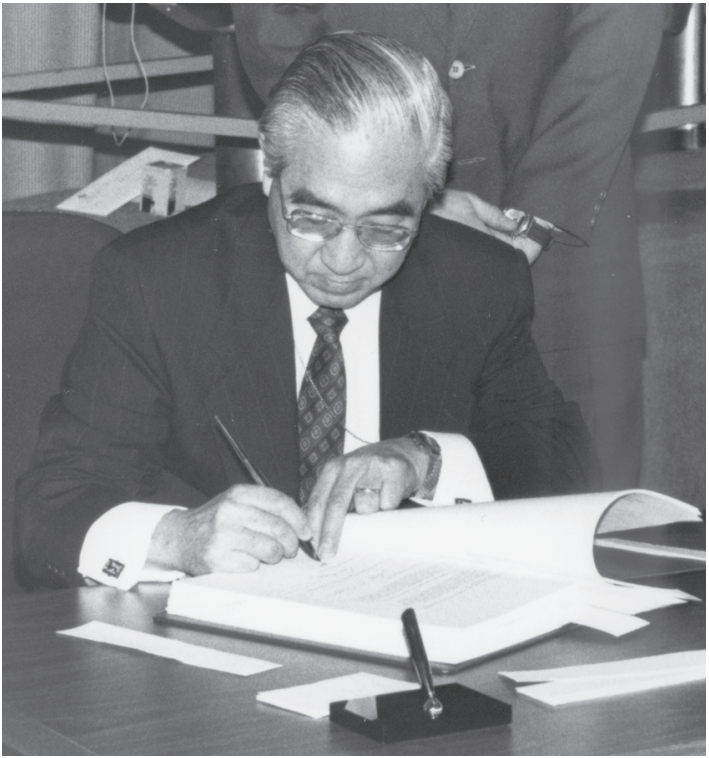

Professor Moritaka Hayashi (1938-2020) ${ }^{1}$

It is with great sadness that the Editors note the death of Professor Moritaka "Mori" Hayashi on 2 April 2020 at the age of 82. They are most grateful to Dr Yoshinobu Takei (UN DOALOS) for his help in drafting this in memoriam. During an illustrious career, Mori served, inter alia, as Director of the Division for Ocean Affairs and the Law of the Sea (DOALOS) of the United Nations Office of Legal Affairs, as Assistant Director-General of the Food and Agriculture Organization of the United Nations (FAO), as well as Professor at the Faculty of Law, Waseda University, Tokyo, Japan. He has been a member of the Editorial Board of the International Journal of Marine and Coastal Law since it was renamed in 1993 as the successor to the International Journal of Estuarine and Coastal Law.

1 Professor Hayashi signing the 1995 Final Act of the UN Fish Stocks Conference, photograph courtesy of UN DOALAS. 
Mori was born in Suzuka, Japan, in 1938. Following his law studies at Waseda University, he conducted his post-graduate studies at Tulane University (LL.M., 1965) and the University of Pennsylvania (M.A., 1966). Following service at the National Diet Library, Japan (1967-1969) and at Hosei University as a lecturer (1969-1971), in 1971 he began a long and successful career at the United Nations Secretariat, initially as a Legal Officer at the Office of Legal Affairs. From 1980 to 1988 , he worked as a Counsellor, and later as a Minister, at the Permanent Mission of Japan to the United Nations in New York.

Returning to the UN Secretariat in 1988, he was the Principal Legal Officer at the Office for Ocean Affairs and the Law of the Sea, later renamed the Division for Ocean Affairs and the Law of the Sea. In 1996, he was promoted to be the Director of that Division. Later, in 1996, he moved to the FAO as the Assistant Director-General for the Fisheries Department, where he remained until 1999.

Following nearly 30 years of public service for both the United Nations system and for the Government of Japan, he returned to his home country to start his new professional life as a Professor at his alma mater, Waseda University in Tokyo, where he was engaged in teaching and research from 1999. In 2008, he became Professor emeritus at Waseda, and also worked as a Special Research Fellow at the Ocean Policy Research Foundation of Japan.

Both as practitioner and as academic, his achievements were important. As a practitioner, his term at the United Nations and at the Japanese Mission covered each of the key milestones in the development of the modern international law of the sea, including the Third United Nations Conference on the Law of the Sea (UNCLOS III), the Informal Consultations on Part XI of the United Nations Convention on the Law of the Sea (which led to the 1994 Implementing Agreement), and the United Nations Conference on Straddling Fish Stocks and Highly Migratory Fish Stocks. He played a role in the birth of all three legal instruments that have formed the pillars of the modern international law of the sea.

In addition to his distinguished career in the practice of the law of the sea, he was a prolific writer: he authored some 90 articles and book chapters in English and Japanese, and authored or co-authored three books, including Gendai Kaiyoho no Seisei to Kadai [The Formation and Challenges of the Modern Law of the Sea (in Japanese)], for which he was awarded a doctoral degree from Waseda University in 2008. His New Directions in the Law of the Sea series, which he co-edited with Dr. Roy S. Lee and updated annually since 1995, has proved a valuable contribution for researchers and practitioners.

His writings cover a wide range of areas in public international law, including United Nations law, the peaceful settlement of disputes, the law of treaties, 
polar law (in particular on the question of Antarctica) and international environmental law. However, it is the international law of the sea to which he has devoted the bulk of his professional career that spanned over 50 years, both as practitioner and as scholar. He has written on virtually all areas of the international law of the sea, including: international straits, fisheries, marine pollution and other issues relating to the marine environment, piracy and maritime terrorism, deep-seabed mining, archaeological and historical objects, international shipping, military uses of the sea, the regime of islands and impacts of sea-level rise.

His contributions to the international law of fisheries and of deep-seabed mining have enduring impacts. In particular, throughout his career at the United Nations and thereafter, he continuously addressed various aspects of fisheries, including issues relating to straddling and highly migratory fish stocks, deep-sea fisheries, illegal, unreported and unregulated fishing, non-flag State enforcement and regional fisheries management. Most importantly, his experience servicing the United Nations Conference on Straddling Fish Stocks and Highly Migratory Fish Stocks, including as its Secretary, which led to the adoption of the 1995 United Nations Fish Stocks Agreement, made his writing on the Agreement all the more valuable for his understanding of the negotiating history and content of the Agreement.

In 2010, Mori and Professor Yukio Shimada co-authored a monograph on the international law of the sea (second edition in 2016 also with Professor Mamoru Koga). The book remains one of the few monographs written in Japanese that address the international law of the sea in a comprehensive manner.

As a mentor and colleague, he was always encouraging and inspiring with his shrewd observations on the theory and practice of the international law of the sea. His broad vision and rigour in his work set a high standard, to which we can all aspire. 